\title{
Growth of Rescues in Natural Areas during the First Summer of COVID-19 Pandemic in Catalonia
}

\author{
Òscar Saladié ${ }^{1,2, * \mathbb{D}}$, Edgar Bustamante ${ }^{1}$ and Aaron Gutiérrez ${ }^{1}$ (D) \\ 1 Department of Geography, Universitat Rovira i Virgili, 43480 Vila-seca, Spain; \\ edgar.bustamante@urv.cat (E.B.); aaron.gutierrez@urv.cat (A.G.) \\ 2 Chair of Sustainable Development Dow/URV, Universitat Rovira i Virgili, 43480 Vila-seca, Spain \\ * Correspondence: oscar.saladie@urv.cat; Tel.: +34-977299481
}

Citation: Saladié, Ò.; Bustamante, E.; Gutiérrez, A. Growth of Rescues in Natural Areas during the First Summer of COVID-19 Pandemic in Catalonia. Land 2021, 10, 498 https://doi.org/10.3390/ land10050498

Academic Editor: Alexander Khoroshev

Received: 11 April 2021

Accepted: 5 May 2021

Published: 7 May 2021

Publisher's Note: MDPI stays neutral with regard to jurisdictional claims in published maps and institutional affiliations.

Copyright: (c) 2021 by the authors. Licensee MDPI, Basel, Switzerland. This article is an open access article distributed under the terms and conditions of the Creative Commons Attribution (CC BY) license (https:/ / creativecommons.org/licenses/by/ $4.0 /)$.

\begin{abstract}
This article analyzes the impact of the end of the COVID-19 lockdown on the number of rescues in natural areas in Catalonia (Spain) during July and August 2020. We compared the figures for 2020 with those corresponding to the same period in 2016-2019, including their temporal and spatial distributions. Our findings show that the number of rescues undertaken by the Catalan Fire Department in July and August 2020 increased significantly compared to the same summer period in the four previous years (+39.7\%). The daily averages increased for both weekends and weekdays in 2020, with 7.5 and 3.9 rescues per day, respectively. The greatest increase corresponded to rescue operations conducted at low altitudes (up to $500 \mathrm{~m} \mathrm{ASL}$ ) and areas with no specific protection status near to populated places. Natural areas were perceived safer than, for example, coastal destinations in terms of the risk of COVID-19 contagion, and they experienced a growth in visitors during the first summer of the pandemic. One consequence of this was an increase in emergency service activity to rescue people in natural areas. This research adds new evidence of the multiple indirect effects of the reconfiguration of mobilities in the context of the COVID-19 pandemic. Our findings could be of interest to emergency service managers, managers of protected natural areas, and public authorities.
\end{abstract}

Keywords: COVID-19; protected natural areas; rescues; emergency services; Catalonia

\section{Introduction}

Protected natural areas play a key role in the conservation of the natural environment and they also provide social benefits such as leisure and recreation space [1]. They need to balance nature conservation objectives, allow certain specific activities or uses [2-5], and contribute to the development of local communities; this is especially true in developing countries [6]. In addition, natural areas are positively associated with human health and wellbeing [7]. Accessibility to protected areas can be restricted in order to prevent their carrying capacities from being exceeded and compromising the sustainability of these areas and the quality of the natural resources that attract visitors [4,8]. However, managers responsible for these protected areas need to have enough resources to apply these kinds of restrictions. There are also some categories of protected areas with regulated uses, but without any managers or management plans. Finally, there are other natural areas which are not subject to a determined protection status.

People who visit natural areas, especially protected areas, participate in a wide range of sporting activities, including mountaineering, rock climbing, cross-country biking, mountain racing, and ski mountaineering, as well as leisure activities such as hiking, walking, and backpacking. Particularly in mountain areas, the former implies an evident risk of accident due to either environmental (adverse conditions) or human (errors in decision making, physical condition, lack of preparation, and/or inappropriate equipment) factors [9]. Individuals participating in these activities may be injured or even killed [10-12]. Hiking may seem a relatively safe activity, but inappropriate footwear, insufficient water, or adverse environmental conditions can produce significant accidents or incidents, even in 
this kind of activity [13]. The incidents can result from a wide range of factors rather than one specific cause related to poor decision making or adverse environmental conditions [14]. The rising number of people involved in outdoor recreation and leisure activities in natural areas has increased the possibility of injury and illness which may require emergency medical attention [15-18], and has led to an increase in the number of rescues carried out [19-21].

The SARS-COV-2 virus has infected more than one hundred million people worldwide, causing over three million deaths [22]. Some national governments established lockdowns and restrictions to control the spread of infection and reduce potential deaths. The beginning and duration of these lockdowns and the types of restrictions imposed depended on each individual country [23]. One of the worldwide restrictions that was applied affected mobility [24-27], as air and land traffic were two of the main vectors for the dissemination of COVID-19 [28-30].

The leisure and tourism sectors have been particularly hard-hit by the pandemic. International and domestic travel for tourism practically ceased during the first months of the pandemic [31]. The UNWTO [32] stated that international arrivals plunged by $74 \%$ in 2020, compared to the previous year, causing an estimated loss of USD 1.3 trillion in export revenue. According to Brouder [33], the COVID-19 crisis has brought tourism activity to a near standstill. Some authors argue that the pandemic could be a starting point to transform tourism activity [34-37] and offer an opportunity for more sustainable and proximity tourism $[38,39]$.

The number of visitors in protected natural areas fell due to lockdown and mobility restrictions [40], confronting benefits (ecological recovery and restoration) with negative impacts when income, preservation activities, and management presence depend on revenues from tourists and visitors, especially in developing countries [41-44]. On the other hand, natural areas have seen a significant increase in the frequency of visitors as mobility restrictions have been relaxed [45]. These places are perceived as being safer than cities or mass tourism destinations in terms of the risk of contagion. Many people have seen them as an escape valve after months of hard lockdown, but they have also generated agglomerations of hikers, climbers, etc. According to McGinley et al. [45], the challenges in managing European protected natural areas due to COVID-19 are as follows: overcrowding, parking and traffic issues, social distancing, problematic behavior by visitors, cancelation of cultural and educational activities, and conflicts between visitors and locals. In regard to overcrowding, the media has highlighted this phenomenon and, in Catalonia (Spain), it has been reported as an "invasion" or "avalanche" of visitors, mainly "escaping" from the Metropolitan Area of Barcelona and placing some natural areas on "the verge of collapse" [46-48]. Some natural areas can combat this threat because they have a determined level of protection [49,50], but many others are not prepared for such an avalanche of visitors, and this is seriously threatening their sustainability [51].

We can assume that the increase in the number of visitors to natural areas (some of which are mountain areas) analyzed in the literature before the COVID-19 pandemic would have followed a rather gradual trend. On the other hand, the stream of people visiting natural areas since the end of lockdown has resulted in an abrupt shift in both the number of people visiting these places [52] and the number of accidents suffered and, as a result, in the number of rescues performed by emergency services [53-55].

In the case of Spain, the State of Alarm decreed by the Spanish Government [23] was in force from 16 March 2020 to 21 June 2020. Since then, restrictions have evolved over time, depending on the public health situation. Taking all of these circumstances into account, our main objectives were to analyze the impact that the end of the COVID-19 lockdown had on (1) number, (2) temporal, and (3) spatial distributions of rescues in natural areas carried out in Catalonia (Spain) during July and August 2020. There were the first two months with no domestic mobility restrictions following a period of three months with strict restrictions on mobility, especially for leisure and tourism purposes. Concretely, we compared the figures for 2020 with those corresponding to the same period in the four previous years 
(2016 to 2019). This research should be useful for those managing emergency services and protected natural areas. It should also contribute new (indirect) evidence to the literature on the multiple effects of the COVID-19 pandemic on tourism and leisure in natural areas.

The rest of this article is organized as follows. The second section is devoted to describe the data and methods, including the area of study. The third section shows the results (temporal and spatial scale). Finally, the main findings are discussed in the fourth section, together with the limitations, implications, and future research lines.

\section{Materials and Methods}

\subsection{Area of study}

Catalonia has a wide network of protected natural areas distributed throughout Catalan territory, including mountain, inland, coastal, and wetland areas. According to the Departament de Territori i Sostenibilitat (DTS; Department of Territory and Sustainability) [56] of the Generalitat de Catalunya (the Autonomous Government of Catalonia), the Catalan System of Natural Protected Spaces is divided into two categories (Figure 1) ${ }^{1}$ : Espais d'Internès Natural (Spaces of Natural Interest; SNI) and Espais Naturals de Protecció Especial (Specially Protected Natural Spaces; SPNS). There are over 140 SNI $\left(\approx 7100 \mathrm{~km}^{2}\right)$, which include the Nature 2000 Network. The SPNSs $\left(\approx 3200 \mathrm{~km}^{2}\right)$ include the only National Park in Catalonia (Aigüestortes i Estany de Sant Maurici) and its peripheral protection zone, 14 Natural Parks, 7 Natural Sites of National Interest, and 64 Nature Reserves. There are other natural areas with no determined protection status.

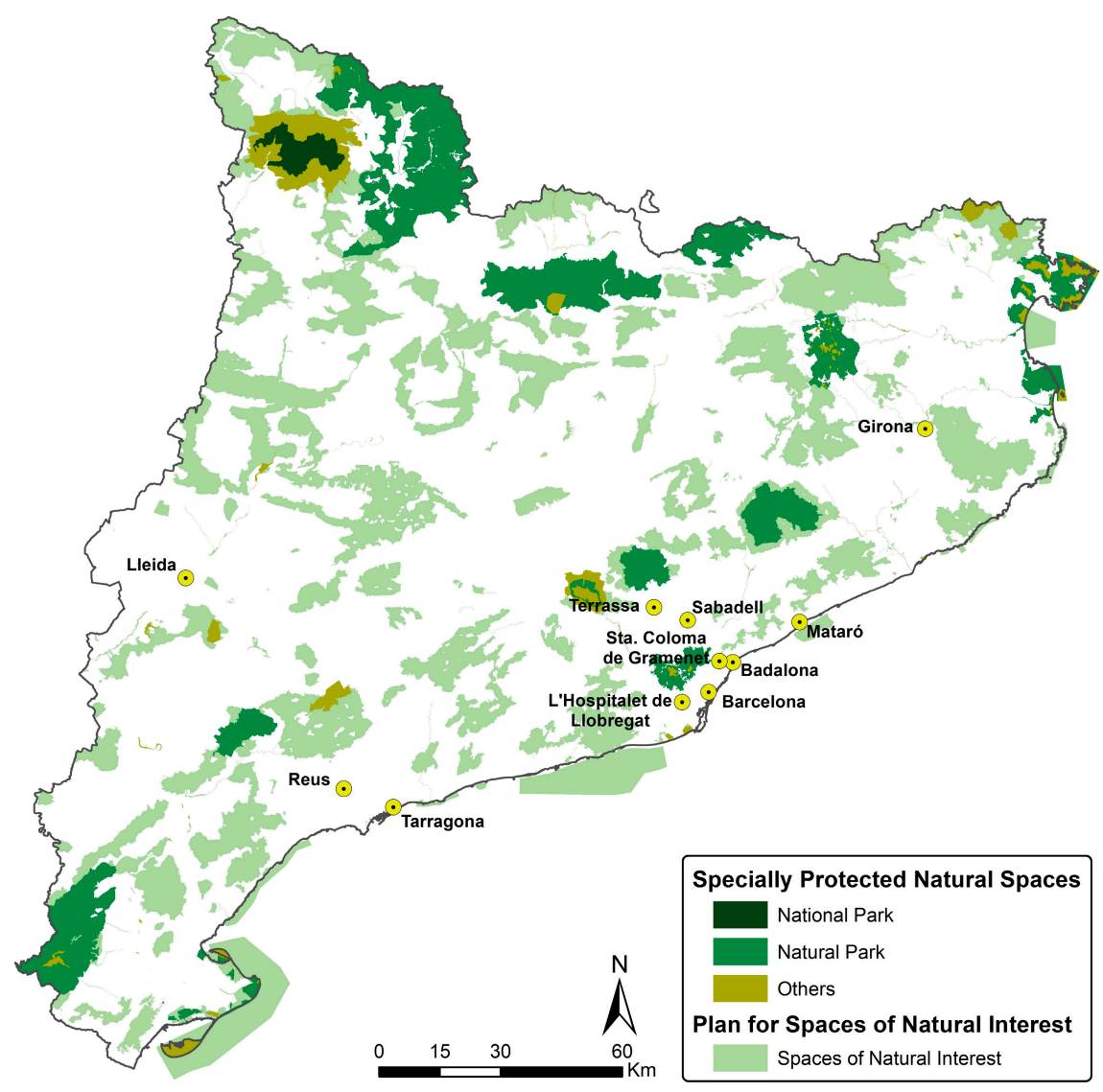

Figure 1. Protected Natural Areas in Catalonia, and towns and cities with over 100,000 people.

Data about the number of visitors in SPNS are of limited availability, and there are no available data for the SNI. Nevertheless, what data are available show that the number of

\footnotetext{
1 For more details: GIS Catalan System of Natural Protected Spaces (http://sig.gencat.cat/visors/enaturals.html, accessed on 11 April 2021).
} 
visitors to most SNPS increased in July and August 2020, compared with the same period in 2019 [52]. For example, increases in the number of people visiting the Aigüestortes i Estany de Sant Maurici National Park (located in the Pyrenees, in the northwest of Catalonia) were $10 \%$ in July and 31\% in August. The increases in visitors to other parks, corresponding to the same months, were: $19 \%$ and $25 \%$ for the Alt Pirineu Natural Park, which is also located in the Western Catalan Pyrenees; $88 \%$ and 57\% for the Cadí-Moixeró Natural Park; and $50 \%$ and $80 \%$ for Capçaleres del Ter i del Fresser. These last two parks are both located in the Central Catalan Pyrenees. The increases in visitors to the three southernmost Natural Parks in Catalonia were: 47\% (July) and 10\% (August) for the Serra de Montsant Natural Park; 100\% and 91\% for the Els Ports Natural Park; and 121\% (August) for the Delta de l'Ebre Natural Park. The first two of these parks are located in the Pre-littoral chain (whose summits are up to $1500 \mathrm{~m}$ above sea level), while the third, which occupies an area created by sediments from the River Ebro, lies at the mouth of this river.

These protected natural areas received larger numbers of visitors than they were used to in the summer of 2020. These new visitors were mainly Catalan people. This was because some mobility restrictions remained in force (i.e., mobility to the rest of Spain and to other countries), and because people were trying to avoid what would usually be crowded destinations. Natural areas were perceived safer than, for example, coastal destinations in terms of the risk of COVID-19 contagion. Nevertheless, perception does not have to coincide with reality [46-48]. In contrast, there was a decrease in the number of visitors to the Aiguamolls de 1'Emporda Natural Park in July (-20\%) and a small increase in visitors in August (+3\%). This is a wetland area located in northeastern Catalonia which receives an important number of visitors from France. International flows were cut due to restrictions on crossing the Hispano-French border. The number of international tourists in Catalonia fell below 4 million in 2020, while they were 19 million in 2019 [57].

\subsection{Data and Methods}

The data on rescues in natural areas (here onwards "rescues") were obtained from the Direcció General d'Extinció, Prevenció d'Incendis i Salvaments (DGPEIS; Directorate General of Fire Prevention, Extinction and Rescue Services) of the Catalan Government, and included information from the Catalan Fire Department. This public department deals with emergencies throughout Catalonia, with the sole exception of the city of Barcelona, which has its own Fire Department.

The Centre d'Atenció i Gestió de Trucades d'Urgència 112 Catalunya (Centre for Attention and the Management of Emergency Calls) centralizes all the emergency calls received via the number 112 and classifies them according to the type of intervention required. The most appropriate emergency service (or services) is then notified: Sistema d'Emergències Mèdiques (SEM; Medical Emergency System) and/or the Mossos d'Esquadra (Catalan Police Department) and/or the Bombers de la Generalitat de Catalunya (Catalan Fire Department). When the Catalan Fire Department is required, information is transferred to the headquarters of the Emergency Region (there are seven in Catalonia) where the emergency incident has occurred. The appropriate resources are then activated according to the type of emergency. For some emergency services, such as mountain rescues, the Grup de Recolzament d'Actuacions Especials (GRAE; Special Activity Support Group) of the Catalan Fire Department can be activated and sent to the scene of the emergency by helicopter.

The target period for our study was from 1 July 2020 to 31 August 2020. However, the dataset facilitated by the DGPEIS started on Monday, 29 June, in order to provide a whole week at the beginning of the period. The DGPEIS also provided data on rescues for the equivalent periods in 2016, 2017, 2018, and 2019, for the same number of weekdays and weekends when a weekly analysis was performed.

The following information was provided for each rescue:

- $\quad$ Date (day, month, and year);

- Time when the rescue started;

- Municipality; 
- UTM coordinates;

- Injuries and deaths at monthly level.

We compared the total number of rescues and the daily averages for both the whole period and for July and August 2020, with those corresponding to the equivalent periods in the period 2016-2019, following a similar approach to that used by Shafiei et al. [58]. The analysis also took into account the following: whether rescues occurred on weekdays or at weekends; the number of people injured or killed; the time at which the rescue started; the altitude at which the rescue took place; the distance to the nearest town with over 100,000 people; and the protection status of the area in which the rescue occurred. Table 1 shows the timeslots chosen, the different altitude thresholds, the different distance thresholds, and the different protection statuses of natural areas. We differentiated three homogeneous diurnal timeslots and one nocturnal timeslot. In the time zone in which the study was conducted and for summer (UTC + 2), the sun rose at 06:20 on $1 \mathrm{July}$, and at 06:45 on 31 August, and set at 21:12 on 1 July, and at 20:28 on 31 August. We established five categories for the altitudes at which rescues took place. The highest mountain in Catalonia is La Pica d'Estats (3143 m ASL), which is in the Pyrenees. We established three categories for the distances from where the rescues took place and the nearest town with over 100,000 people. We differentiated three different categories for the protection status of where the rescue took place: Specially Protected Natural Space (SPNS), Space of Natural Interest (SNI), and other natural spaces.

Table 1. Timeslots, altitude and distance thresholds, and natural area protection status.

\begin{tabular}{cccc}
\hline Time & Altitude & Distance & Protection Status \\
\hline $06: 01-11: 00$ & $\leq 250 \mathrm{~m}$ & $\leq 50 \mathrm{~km}$ & Specially Protected Natural Space (SPNS) \\
11:01-16:00 & $251-500 \mathrm{~m}$ & $50.1-100 \mathrm{~km}$ & Space of Natural Interest (SNI) \\
16:01-21:00 & $501-1000 \mathrm{~m}$ & $>100 \mathrm{~km}$ & Other natural spaces \\
$21: 01-06.00$ & $1001-2000 \mathrm{~m}$ & & \\
& $>2000 \mathrm{~m}$ & & \\
\hline
\end{tabular}

We used a $t$-test to compare averages for rescues. The Kolmogorov-Smirnov test showed that the distribution matched the characteristics of a normal distribution. The chi-square test $\left(\chi^{2}\right)$ was applied to analyze whether the differences in the distribution of rescues were statistically significant. Finally, we used a Kernel density estimation function (natural break method) to calculate the concentration of the rescues corresponding to July and August in 2016, 2017, 2018, 2019, and 2020. This estimation computed a magnitude per unit area, based on point or polyline features, using a Kernel function to fit a smoothly tapered surface to each point or polyline. This enabled us to produce a series of heat maps showing the highest and lowest concentrations of rescues in each of the periods studied. Kernel density estimation is a well-established technique for conducting studies using Geographical Information Systems and spatial-analysis approaches to reveal spatial patterns of the deployment of emergency services [58].

\section{Results}

\subsection{Temporal Distribution of Rescues}

Table 2 shows the number of rescues and causalities involving the intervention of the Catalan Fire Department during July and August in 2016, 2017, 2018, 2019, and 2020, and the daily average for the period 2016-2019. More than 300 rescues took place during these two months in 2020, at an average of 4.9 per day. The number of rescues registered during the study period revealed an increase of $39.7 \%$ compared to the average for the same months during the reference period. The average number of daily rescues for the period of 20162019 was 3.5, and the difference was statistically significant ( $t$-value $=3.22724 ; p<0.05$ ). The increase in the average number of daily rescues was greater in August $(+52.6 \%)$ than in July (+25.7\%). There were 3.7 and 5.6 in August for 2016-2019 and in 2020, respectively, while the respective July values were 3.4 and 4.3. However, the differences were only 
statistically significant for August $(t$-value $=3.53601 ; p<0.05)$. Consequently, although the distribution of rescues between July and August slightly changed, the difference in the distribution was not statistically significant $\left(\chi^{2}=1.1915 ; p\right.$-value $\left.=0.275022\right)$.

Table 2. Frequency and daily mean number of rescues and causalities.

\begin{tabular}{cccc}
\hline & & Rescues (\%)-Daily Mean & Total \\
\cline { 2 - 4 } & July & August & $306-4.9$ \\
2020 & $132(43.1 \%)-4.3$ & $174(56.9 \%)-5.6$ & $219-3.5$ \\
\hline $2016-2019$ & $105(47.9 \%)-3.4$ & $114(52.1 \%)-3.7$ & $217-3.5$ \\
2016 & $108(49.8 \%)-3.5$ & $109(50.2 \%)-3.5$ & $208-3.4$ \\
2018 & $98(47.1 \%)-3.2$ & $110(52.9 \%)-3.5$ & $209-3.4$ \\
2019 & $111(53.1 \%)-3.6$ & $98(46.9 \%)-3.5$ & $241-3.9$ \\
\hline & $104(43.2 \%)-3.4$ & $137(56.8 \%)-4.4$ & Total \\
\hline 2020 & & Injuries and Deaths (\%)-Daily Mean & $216-3.5$ \\
$2016-2019$ & July & August & $159-2.6$ \\
\hline 2016 & $84(38.9 \%)-2.7$ & $132(62.1 \%)-4.3$ & $149-2.4$ \\
2018 & $75(47.2 \%)-2.4$ & $84(52.8 \%)-2.7$ & $161-2.6$ \\
\hline & $75(50.3 \%)-2.4$ & $74(49.7 \%)-2.4$ & $154-2.5$ \\
\hline
\end{tabular}

Emergency teams found people with different kinds of injury and, in worst of cases, dead. Table 2 also shows the monthly distribution of casualties (injured and dead). There were 216 casualties (seven deaths) in 2020; this was approximately one third more than the mean for 2016-2019, and a quarter more than in the year with the highest number of casualties in the reference period (2019). The daily mean for 2020 was 3.5; the value remained very stable during the four-year reference period. The observed increase was mainly due to August $2020(+57.1 \%)$, while the increase was more moderate in July $(+12 \%)$. Even so, the differences in the distributions between July and August were not statistically significant $\left(\chi^{2}=2.57156 ; p\right.$-value $\left.=0.108804\right)$.

Figure 2 shows the evolution of rescues from Wednesday 1 July to Monday 31 August 2020, and the mean value for the period 2016-2019. The 62-day period covered resulted from the different start dates: Wednesday 29 June in 2016; Wednesday 28 June in 2017; Wednesday 4 July in 2018; and Wednesday 3 July in 2019. This makes it possible to match weekdays and weekends for the two samples. As expected, there was less variability in the daily mean value for the period 2016-2019. We can see how there are small differences between the two lines corresponding to July, where it is possible to highlight the anomalous value for Sunday, 19 July 2020, when there were 16 rescues. Conversely, the figure depicts evidently different behavior in August when we compare 2020 and the period 2016-2019. There were 7 rescues in 11 days in 2020. We should also highlight Sunday, 9 August, with 14 rescues. There were seven rescues in only five days in 2019, as well as in two days in 2018, in two days in 2017, and in three days in 2016.

Figure 3 shows the weekly distribution (from Monday to Sunday) of rescues. In 2020, the first week corresponds to the period between Monday, 29 June and Sunday, 5 July, while the ninth (and final) week was between Monday, 24 August and Sunday, 30 August. Only in the fifth week (27 July-2 August) was the number of rescues below the figure for the same week in the period 2016-2019. Nevertheless, these differences were only magnified in three of the nine weeks: the fourth (20-26 July), the sixth (3-9 August), and especially the eighth (17-23 August-51 rescues). The largest number of rescues registered in a week, in any of the four reference years, corresponded to the seventh week of 2019, with 39.

Table 3 shows the distribution of rescues, taking into account whether they occurred on weekdays or at weekends. More than half (55.9\%) occurred on weekdays in 2020; this did not match the distribution of days between weekdays and weekends. A greater ratio of rescues is expected to occur at weekends than on weekdays. The daily averages for 
the period 2016-2019 were 5.3 and 2.8, respectively. The daily averages increased for both weekends and weekdays in 2020, with 7.5 and 3.9 rescues per day, respectively. The number of rescues registered at weekends in 2020 represented an increase of $41.3 \%$ compared to the average for the equivalent period in 2016-2019. This was more pronounced in August $(+51.3 \%)$ than in July $(+28.3 \%)$. On the other hand, the increase on weekdays was slightly lower $(+37.8 \%)$ than at weekends. It was also greater in August $(+54.3 \%)$ than in July $(+23.1 \%)$. There was therefore an increase in the number of daily rescues in all cases. We should also highlight the average of eight rescues per day at weekends in July 2020. These differences were statistically significant when we compared values for weekdays between 2020 and the period 2016-2019 $(t=2.9487 ; p<0.05)$, and also when we compared weekends $(t=2.45316 ; p<0.05)$. Even so, differences in the weekday/weekend distribution between 2020 and 2016-2020 were not statistically significant $\left(\chi^{2}=0.0206\right.$; $p$-value $\left.=0.885865\right)$.

Table 4 shows the timeslots in which the emergency services started rescues. Half of them started between 11.01 and 16.00, in both 2020 and the reference period (2016-2019). As expected, the lowest incidence of cases happened at night. The number of rescues in 2020 increased in all four timeslots, but it is particularly relevant to highlight those starting in the morning (06.01-11.00). Despite a notable increase $(+83.3 \%)$ in the number of rescues in this timeslot, it only accounted for less than $15 \%$ of the total. The other timeslots saw their relative weights slightly reduced. Even so, the difference in the distribution was not statistically significant $\left(\chi^{2}=1.4305 ; p\right.$-value $\left.=0.698405\right)$.

Figure 4 shows the relative frequency of rescues per hour in 2020, and for each of the four years in the reference period. The year 2020 showed no clear peak and a similar distribution from 12.00 to 15.00. The year 2017 showed a similar distribution to 2020 (from 12.00 to 16.00). However, 2016 and 2019 showed a marked peak at around 14.00, respectively, accounting for $10 \%$ and $12 \%$ of the total number of rescues in July and August. There was also a marked peak in 2018 at around $13.00(>12 \%)$.

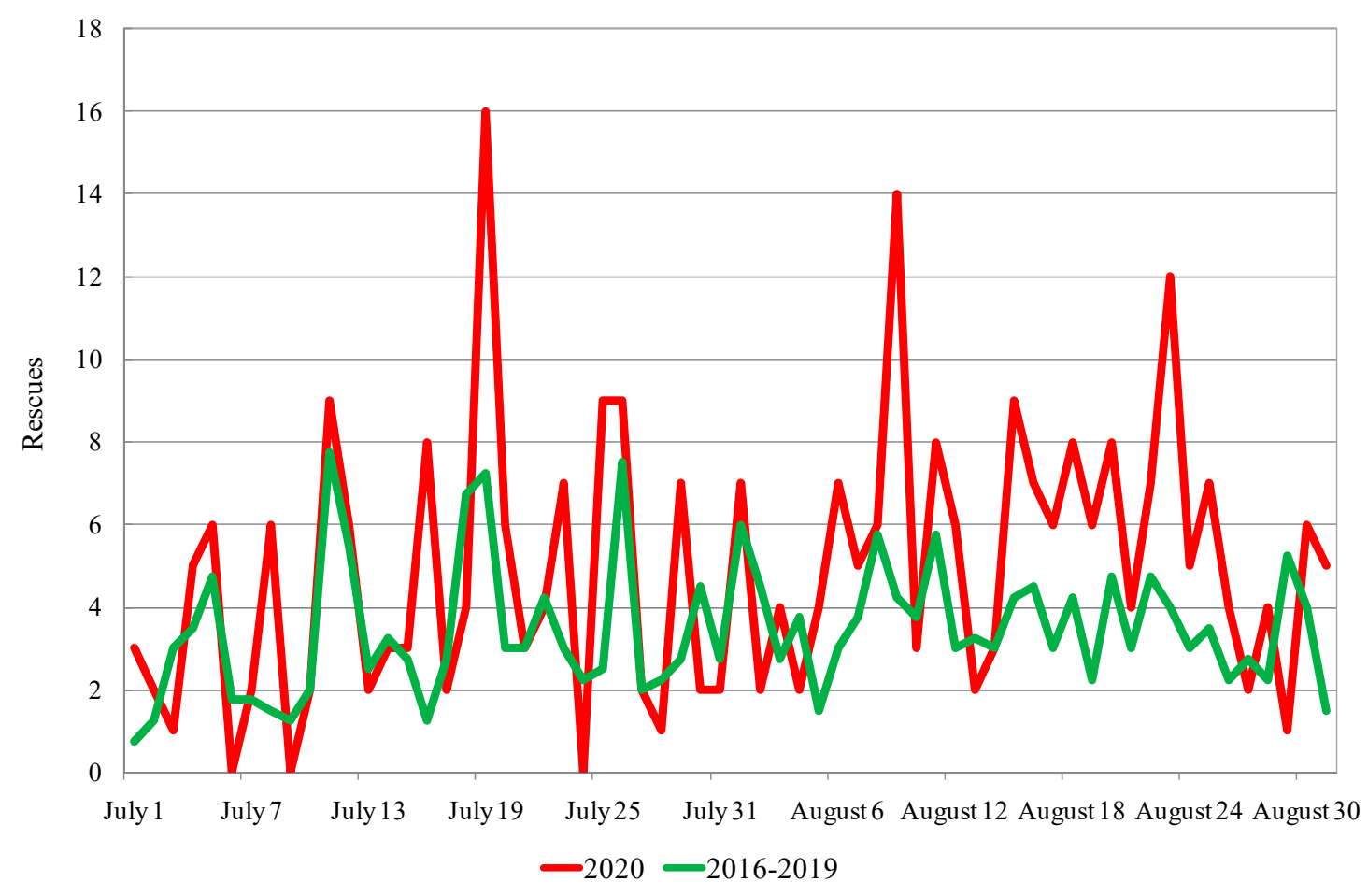

Figure 2. Daily distribution of rescues from 1 July to 31 August 2020 and equivalent period for 2016-2019. 


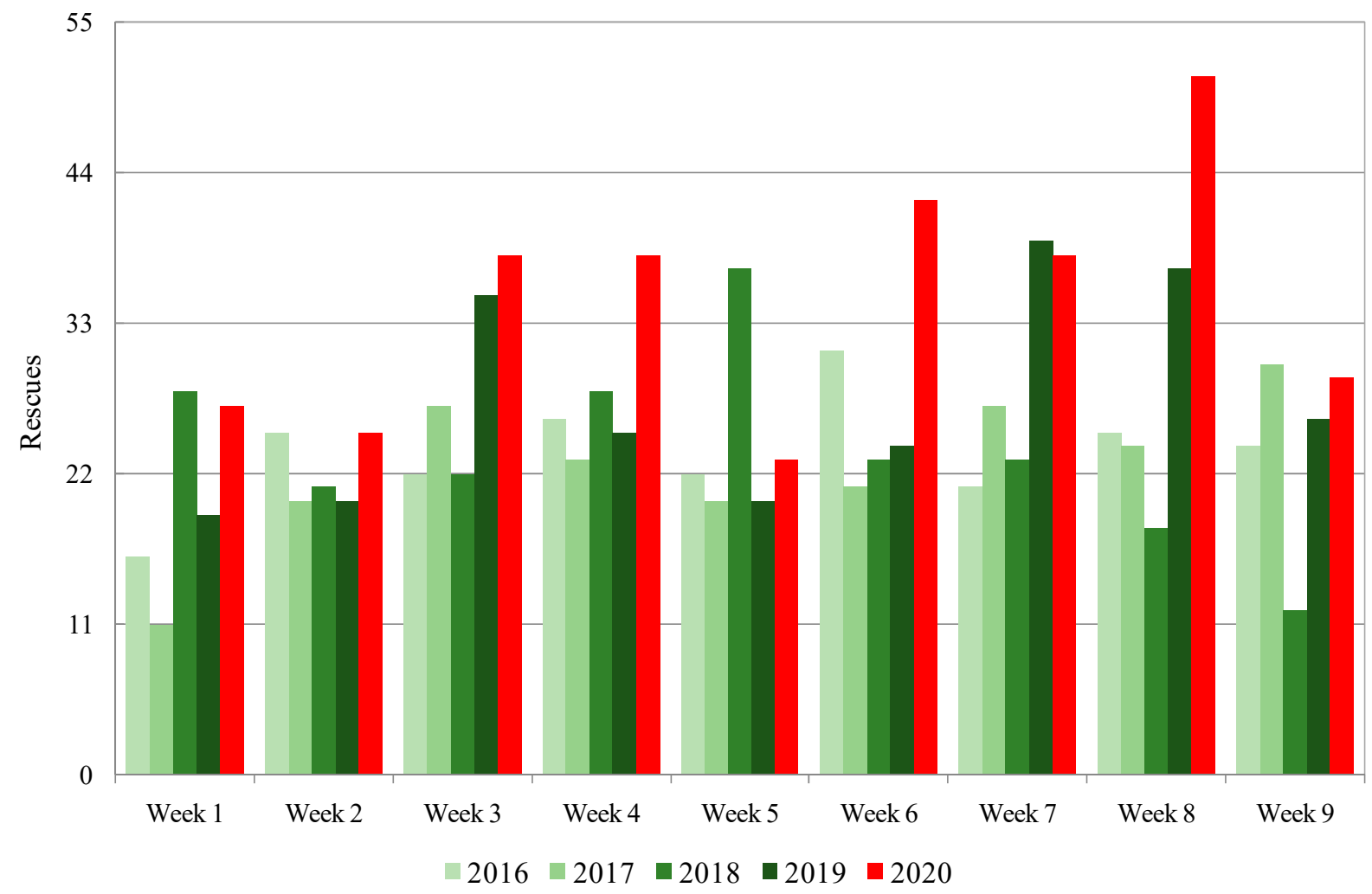

Figure 3. Weekly distribution of rescues from Monday, 29 June and Sunday, 30 August 2020 and equivalent periods for 2016, 2017, 2018, and 2019.

Table 3. Frequency and daily mean number of rescues on weekdays and at weekends.

\begin{tabular}{ccccc}
\hline \multirow{2}{*}{2} & \multicolumn{3}{c}{ Rescues (\%)-Daily Mean } \\
\cline { 3 - 5 } & & July & August & Total \\
\hline \multirow{2}{*}{2020} & Weekdays & $68(51.5 \%)-3.0$ & $103(59.2 \%)-4.9$ & $171(55.9 \%)-3.9$ \\
& Weekends & $64(48.5 \%)-8.0$ & $71(40.8 \%)-7.1$ & $135(44.1 \%)-7.5$ \\
\hline \multirow{2}{*}{$2016-2019$} & Weekdays & $53(50.5 \%)-2.4$ & $68(59.6 \%)-3.1$ & $121(55.3 \%)-2.8$ \\
& Weekends & $52(49.5 \%)-5.6$ & $46(40.4 \%)-5.0$ & $98(44.7 \%)-5.3$ \\
\hline
\end{tabular}

Table 4. Frequency of rescues for different timeslots.

\begin{tabular}{cccc}
\hline Timeslot & $\mathbf{2 0 2 0}$ & $\mathbf{2 0 1 6 - 2 0 1 9}$ & $\mathbf{\Delta \%}$ \\
\hline $06: 01-11: 00$ & $44(14.4 \%)$ & $24(11.1 \%)$ & $+83.3 \%$ \\
11:01-16:00 & $153(50.0 \%)$ & $111(50.5 \%)$ & $+37.6 \%$ \\
16:01-21:00 & $90(29.4 \%)$ & $69(31.4 \%)$ & $+30.4 \%$ \\
$21: 01-06: 00$ & $19(6.2 \%)$ & $15(7.0 \%)$ & $+26.7 \%$ \\
\hline
\end{tabular}

\subsection{Spatial Distribution of Rescues}

Figure 5 shows the spatial distribution of the rescues in 2020 and for each one of the four reference years. There were a lot of rescues in the northern area, corresponding to the Pyrenees, where several summits rise to heights of around $3000 \mathrm{~m}$ ASL. The distribution of the incident points on the map for 2020 also highlighted the Pre-littoral chain, which runs southwest to northeast. There, the highest summits are under $2000 \mathrm{~m}$ ASL. The locations of rescues also highlighted another mountain chain running parallel to the Pre-littoral chain and between it and the Mediterranean Sea (the Littoral chain), whose highest summits are under $1000 \mathrm{~m}$ ASL. It is also relevant to highlight rescues in areas along the coast, especially in the northeastern area of Catalonia (a rocky coast). The same pattern was found on the 
rest of the maps. The main difference was the large number of rescues in 2020, which outlined the Pre-littoral chain and, especially, the Littoral chain in a much clearer way.
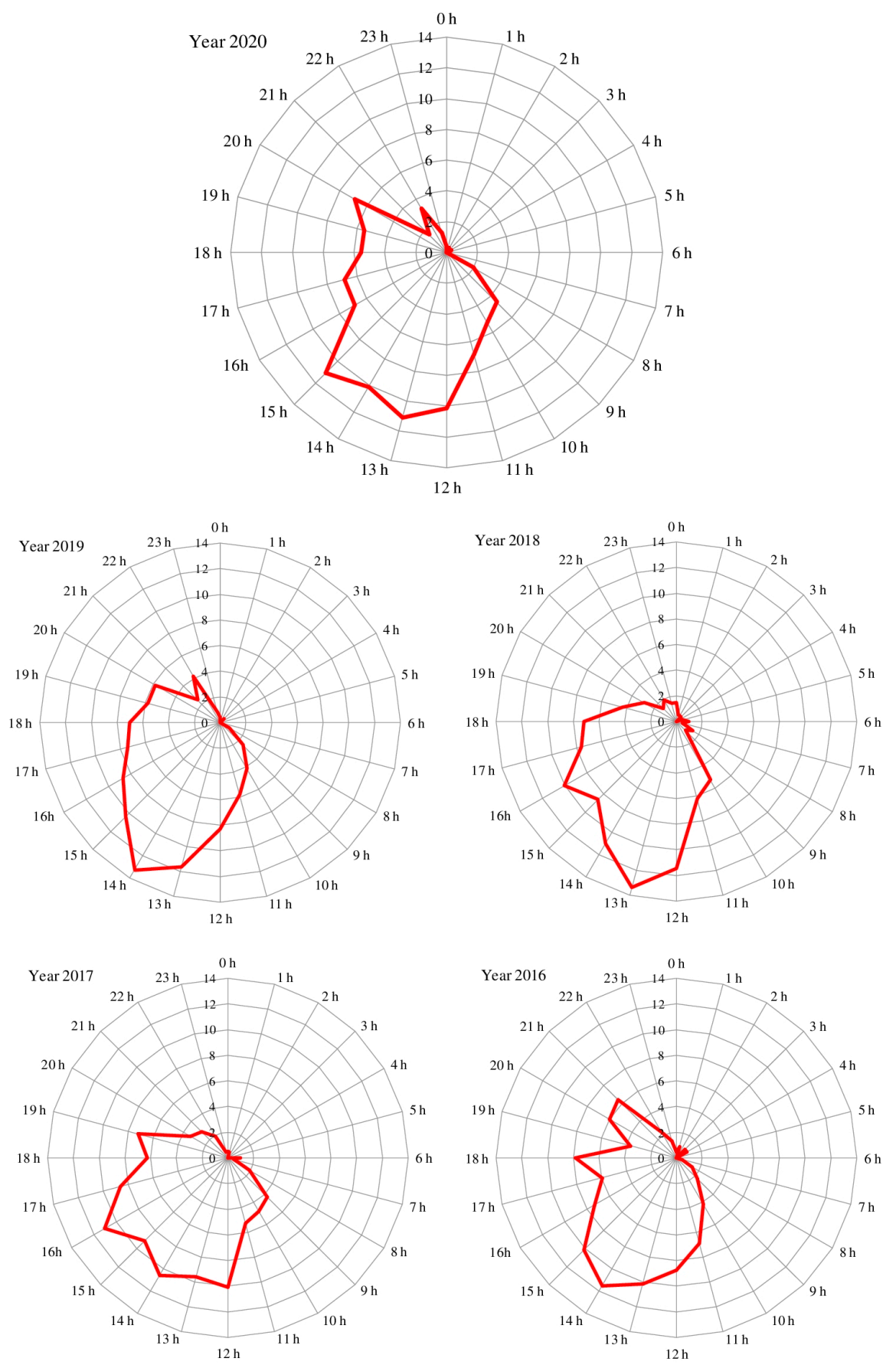

Figure 4. Relative frequency of the hourly distribution of rescues.

Table 5 shows the distribution of different rescue operations, taking altitude into account and comparing data for 2020 with mean values for the reference period of 20162019. The number of rescues increased in all five of our thresholds. The greatest increase corresponded to rescue operations conducted at low altitudes (up to $500 \mathrm{~m}$ ASL). More than one quarter of the rescues during the reference period took place at altitudes between 1001 and $2000 \mathrm{~m}$ ASL. The number increased in $2020(+17.2 \%)$ but decreased in terms of their relative frequency, accounting for the same number as occurred at between 501 and $1000 \mathrm{~m}$ ASL and with only two more than those occurring at altitudes up to $250 \mathrm{~m}$ ASL. 
Nevertheless, the difference in the distribution was not statistically significant $\left(\chi^{2}=5.79\right.$; $p$-value $=0.215388)$.
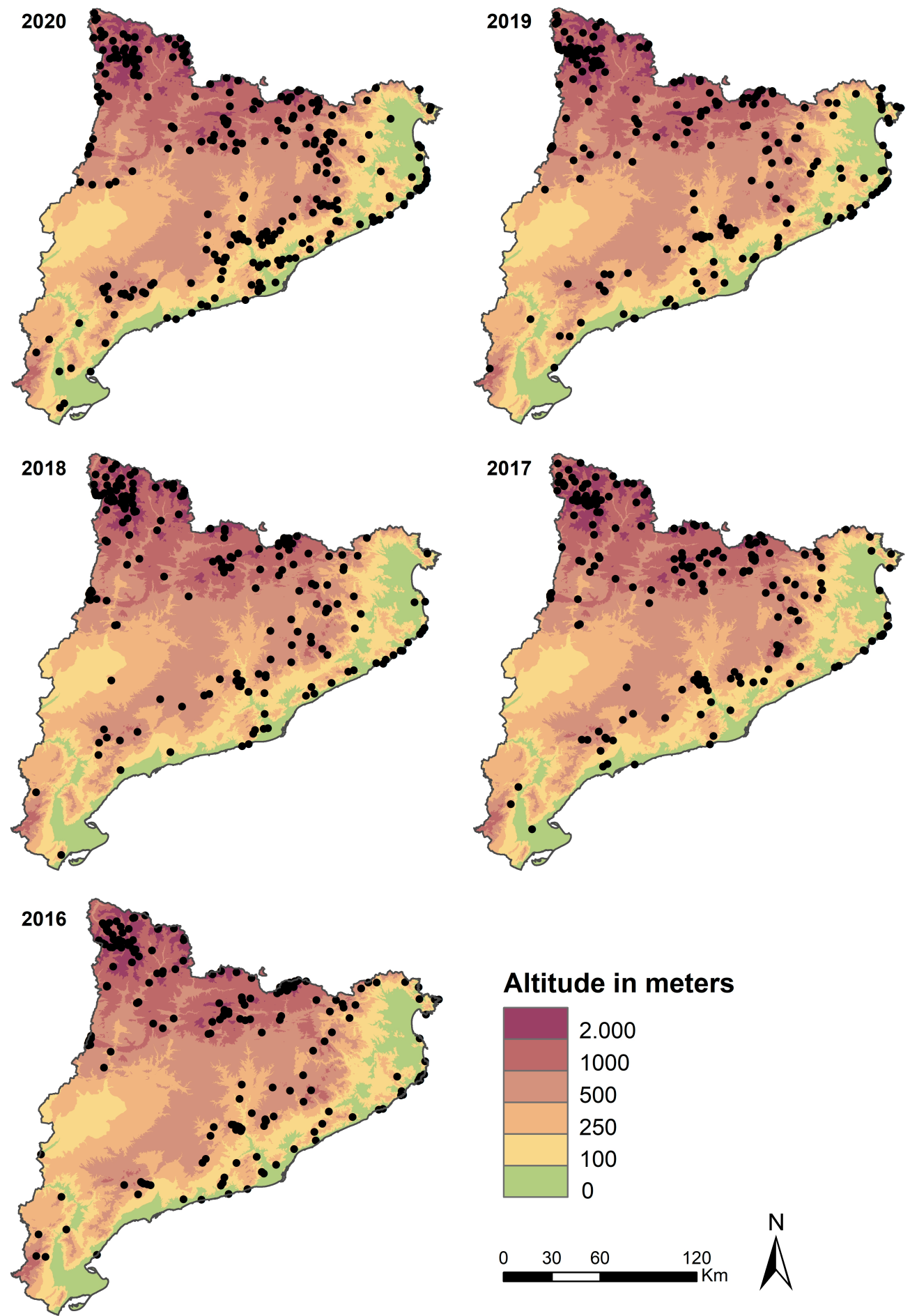

Figure 5. Spatial distribution of rescues and their altitude.

Table 6 shows the distribution of rescues according to the protection status of where the rescue took place. On average, the category with the highest level of protection (SPNS) accounted for two out of every five rescues during the reference period (2016-2019). This was followed by other natural areas and SNI with similar ratios (three out of ten). All categories showed an increase in the number of rescues, but especially those corresponding 
to other natural areas, which was in first position in 2020 and accounted for more than $40 \%$ of all incidents. As a result, the other two categories fell in terms of relative frequency. Nevertheless, the difference in the distribution was not statistically significant $\left(\chi^{2}=4.9384\right.$; $p$-value $=0.084651)$.

Table 5. Frequency of rescues at different altitudes.

\begin{tabular}{cccc}
\hline Altitude & $\mathbf{2 0 2 0}$ & $\mathbf{2 0 1 6 - 2 0 1 9}$ & $\boldsymbol{\Delta} \%$ \\
\hline$\leq 250 \mathrm{~m}$ & $66(21.6 \%)$ & $37(16.9 \%)$ & $+78.4 \%$ \\
$251-500 \mathrm{~m}$ & $52(17.0 \%)$ & $28(12.8 \%)$ & $+85.7 \%$ \\
$501-1000 \mathrm{~m}$ & $68(22.2 \%)$ & $48(21.9 \%)$ & $+41.7 \%$ \\
$1001-2000 \mathrm{~m}$ & $68(22.2 \%)$ & $57(26.0 \%)$ & $+19.3 \%$ \\
$>2000 \mathrm{~m}$ & $52(17.0 \%)$ & $49(22.4 \%)$ & $+6.1 \%$ \\
\hline
\end{tabular}

Table 6. Frequency of rescues and the protection status of natural areas.

\begin{tabular}{cccc}
\hline Protection Status & $\mathbf{2 0 2 0}$ & $\mathbf{2 0 1 6 - 2 0 1 9}$ & $\boldsymbol{\Delta} \%$ \\
\hline SPNS & $107(35.0 \%)$ & $89(40.8 \%)$ & $+20.2 \%$ \\
SNI & $75(24.5 \%)$ & $62(28.2 \%)$ & $+21.0 \%$ \\
Other & $124(40.5 \%)$ & $68(31.0 \%)$ & $+82.4 \%$ \\
\hline
\end{tabular}

Figure 6 shows the spatial distribution of rescues in 2020 and for each one of the four reference years, showing these data on the map depicting the protected areas (SPNS and SNI). The greatest number of rescues in July and August 2020 corresponded to the Aigüestortes i Estany de Sant Maurici National Park, with 37-more than one rescue every two days, representing one third of those in SPNS. There was an increase of almost $40 \%$ in comparison with the mean value for 2016-2019 (27) and 16\% with respect to 2019 (32).

The protected natural area with the second highest number of rescues was the Montserrat Natural Park, with $19(+43 \%$ and $+46 \%$, respectively, compared with 2016-2019 and 2019), followed by the Alt Pirineu Natural Park, with 14 ( $+37 \%$ and $+100 \%$, respectively, compared with 2016-2019 and 2019). No other Natural Park registered more than 10 rescues. Nevertheless, the eight carried out in the Montseny Natural Park represented an increase of 167\% with respect to 2016-2019, and 300\% compared to 2019; the seven rescues in the Zona Volcànica de la Garrotxa Natural Park represented an increase of 200\% with respect to 2016-2019, and 100\% compared to 2019. On the other hand, the number of rescues decreased by 63\% in the Cadí-Moixeró Natural Park when comparing 2020 (three) and 2016-2019 (eight), and by 53\% in the Capçaleres del Ter i del Fresser Natural Park when comparing 2020 (eight) and 2019 (17).

The only SNI in which there were 10 rescues was Muntanyes de Prades, a protected natural area near the Metropolitan Area of Tarragona-Reus. The increase was $122 \%$ compared to 2016-2019 and 67\% with respect to 2019. Most of rescues in other natural areas took place near the Metropolitan Area of Barcelona or near the Pyrenees.

Table 7 shows the distribution of rescues, taking into account the distance from where the rescue occurred and the nearest town with over 100,000 people, and comparing data for 2020 with mean values for the reference period of 2016-2019. The number of rescues increased in all three of our thresholds. Nevertheless, the greatest increase corresponded to rescue operations at low distances $(+74.2 \%)$. They accounted for more than half of rescues during July and August 2020. The other two thresholds fell in terms of relative frequency. The difference in the distribution was statistically significant $\left(\chi^{2}=6.1187 ; p\right.$-value $\left.<0.05\right)$.

Finally, Figure 7 shows the spatial concentration of rescues in Catalonia between 2016 and 2020. The maps highlight the key role of three variables: altitude/orography, protected natural areas, and proximity to populated areas. The only hotspot (red, denoting a very high concentration) seen on all the maps corresponds to the Western Catalan Pyrenees, and is related to the Aigüestortes i Estany de Sant Maurici National Park. There is another area with a very high concentration of rescues, but only in 2020. That relates to the area that includes the Montserrat and Sant Llorenç del Munt i de l'Obac Natural Parks. This area is very close to the Metropolitan Area of Barcelona. 

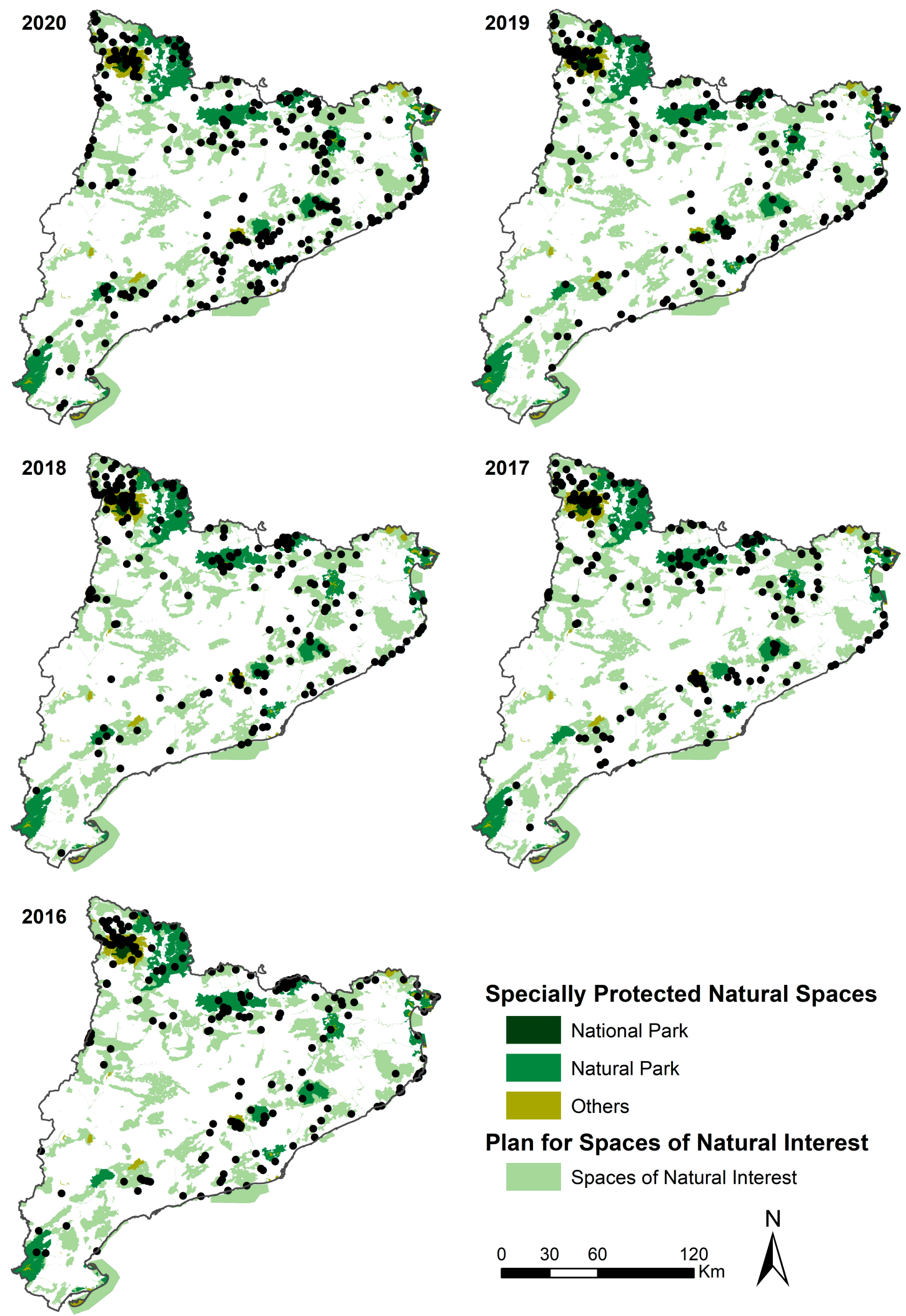

Specially Protected Natural Spaces

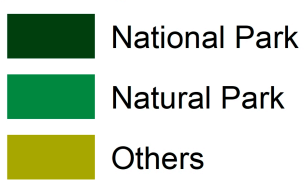

Plan for Spaces of Natural Interest

Spaces of Natural Interest

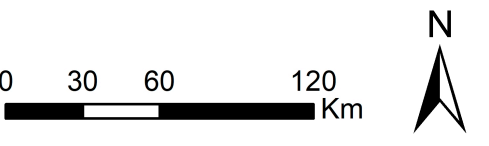

Figure 6. Spatial distribution of rescues and protection status. 
Table 7. Frequency of rescues and distance to the nearest town with over 100,000 people.

\begin{tabular}{cccc}
\hline Distance & $\mathbf{2 0 2 0}$ & $\mathbf{2 0 1 6 - 2 0 1 9}$ & $\boldsymbol{\Delta} \%$ \\
\hline$\leq 50 \mathrm{~km}$ & $169(55.2 \%)$ & $97(44.3 \%)$ & $+74.2 \%$ \\
$50.1-100 \mathrm{~km}$ & $71(23.2 \%)$ & $64(29.2 \%)$ & $+10.9 \%$ \\
$>100 \mathrm{~km}$ & $66(21.6 \%)$ & $58(26.5 \%)$ & $+13.8 \%$ \\
\hline
\end{tabular}
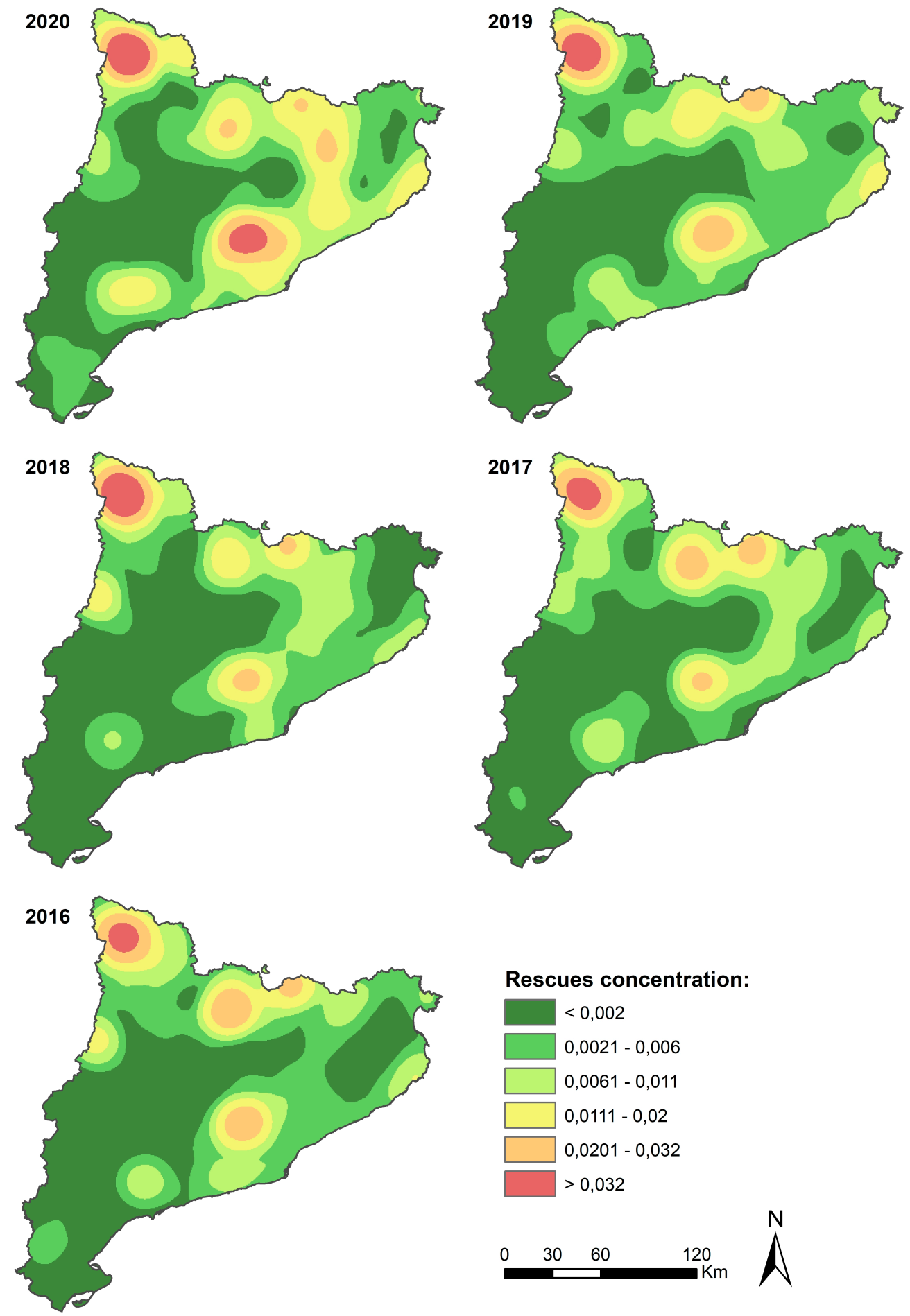

Figure 7. Spatial concentration of rescues. 
The map for 2020 shows three areas with high concentrations (orange), all of which are in the Pyrenees. From west to east, they are: Cadí-Moixeró, Capaçaleres del Ter i del Fresser, and Zona Volcànica de la Garrotxa Natural Parks. The second of these maintained the same category as in the four previous years, the first was only in this category in 2016 and 2017, and the third was in this category for the first time. There are also three areas corresponding to the third level (yellow) of rescue concentration in 2020. From southwest to northeast, these were: the area comprising the Serra de Montsant Natural Park and the Muntanyes de Prades SNI, the Montseny Natural Park, and a rocky coastal area. The increase in the total number and in the territorial dispersal of rescues in 2020 implied a reduction in the area with a low or moderate concentration of rescues (green) and an increase in the area with a high or very high concentration (yellow, orange, and red).

\section{Discussion and Conclusions}

\subsection{Main Findings}

Our findings show that the number of rescues undertaken by the Catalan Fire Department in July and August 2020 increased significantly compared to the same summer period corresponding to the four previous years. While the number of these kinds of rescue may vary from year to year, the considerable difference noted between the study period (July and August) in 2020 and the equivalent period in 2016-2019, with an increase of almost $40 \%$ and an incidence of almost five rescues per day, could mainly be attributed to the reconfiguration of leisure mobilities due to COVID-19. To be more precise, it would seem related to the June 21 revocation of the initial period of lockdown, which had been decreed by the Spanish Government three months earlier, and also to the relaxation of some of the restrictions on mobility, enforced to combat the spread of COVID-19.

In Catalonia, natural areas received larger numbers of visitors than before in the summer of 2020 [52]. This was partly because some mobility restrictions remained in force (i.e., mobility to the rest of Spain and other countries) and because people were trying to avoid what would usually be crowded destinations. Natural areas were perceived as safer than, for example, coastal destinations in terms of the risk of COVID-19 contagion. One of the consequences of this was an increase in emergency service activity to rescue people in natural areas. The growth in the number of people visiting these areas also increased the probability of them having accidents there [15,18,53-55]. Undertaking activities in natural areas often involves a certain element of risk.

The reasons for accidents (human, environmental, etc.) have already been analyzed in some depth in the literature $[9,13,14]$, and accidents are more likely when people visit natural areas that they do not know well (due to inappropriate preparation, etc.). However, activities such as climbing are very different from others such as hiking, and when accidents occur, their consequences may include a wide range of injuries, or even death [59-62].

Regarding the temporal distribution of rescues, the number increased in both July and August 2020, but it was twice as high as in the latter. The potential number of visitors to natural areas was greater in August than in July because most Catalan people have their holidays in August. Catalonia also tends to receive a huge number of tourists from the rest of Spain and other countries in summer, especially in August. Nevertheless, many Catalan people normally spend their holidays outside Catalonia, or at other Catalan destinations, particularly on the coast, participating in activities where the probability of needing to be rescued is low. The number of both international tourists and those from other parts of Spain fell in August 2020, but so also did the stream of Catalan residents traveling outside Catalonia and/or visiting other Catalan destinations considered "less safe" in terms of potential COVID-19 contagion. The result was an increase in the number of visitors to protected natural areas, but also to natural areas with no protection status in the summer of 2020 and, especially, in August of that year. There was consequently a significant increase in the number of rescues undertaken by the Catalan Fire Department. The greatest increase in rescues occurred in August rather than July, and this is also shown by daily and weekly distributions. 
The number of rescues increased both at weekends and on weekdays, and the differences between them also increased in terms of daily rescues. The increase in rescues at weekends was greater in July than in August, and greater on weekdays in August. Natural areas probably received more visits (daily average) at weekends than on weekdays in July because many people would have been working rather than on holiday in that month. On the other hand, despite the average number of daily rescues being greater at weekends in August than on weekdays, the difference between the two was smaller than in July because many people decided to visit a natural area on a weekday due to the previously mentioned restrictions on mobility and/or perceived health risk/safety.

The number of rescues also increased in each of the four timeslots we defined. However, this increase was by around $25 \%-40 \%$ in three of them, but by more than $80 \%$ when the rescue started at between 06.01 and 11.00. This could perhaps be explained by the fact that many people would have visited natural areas near where they lived. They would therefore have been able to arrive at their chosen destination earlier than it had been located farther away. Nevertheless, the rescues performed during that timeslot represented fewer than $15 \%$ of the total. Half of these occurred between 11.01 and 16.00 in both 2020 and the period 2016-2019.

The distribution of rescues according to altitude showed increases for all five of the thresholds defined. Nevertheless, there was a clear pattern revealing a greater increase in the number of rescues with decreasing altitude, with around $80 \%$ in the lowest altitude band ( $<500 \mathrm{~m}$ ASL) but one of only 6\% above $2000 \mathrm{~m}$ ASL, comparing data for 2020 with 2016-2019. The surface area over $1000 \mathrm{~m}$ ASL represents only $20 \%$ of the total but accounted for $39 \%$ of the rescues carried out. The number of rescues performed by the Catalan Fire Department at high altitude locations remained more stable. This was probably because most of the "new visitors" to natural areas chose places near where they lived. The highest summits are located far away from the most populated areas. However, people can also perform some risky activities at low altitudes, and a lack of preparation implies an increased degree of risk. Furthermore, an excess of confidence can lead to an accident, regardless of the activity or the altitude/orography.

The number of rescues also increased in all three categories based on protection status: Specially Protected Natural Spaces (SPNS), Spaces of Natural Interest (SNI), and other natural areas. The numbers were very similar in the cases of SPNS and SNI (+20\%), but significantly different for the third category, in which the number of rescues rose from 68 in 2016-2019 to 124 in 2020 (+80\%) — the highest number in any of the three categories. However, the total surface area corresponding to the SPNS is almost $3200 \mathrm{~km}^{2}$ and that of the SNI is $7100 \mathrm{~km}^{2}$. This implies one rescue for every $30 \mathrm{~km}^{2}$ and $95 \mathrm{~km}^{2}$, respectively, while Catalonia has a total surface area of around $32,000 \mathrm{~km}^{2}$ (including urban areas).

The analysis of the spatial concentration of rescues shows how the Pyrenees (in the highest altitude category), and especially the western part of the Pyrenees, where the Aigüestortes i Estany de Sant Maurici National Park is located, remains the area with the highest concentration of accidents. The mountainous area (Pre-littoral chain) surrounding the Metropolitan Area of Barcelona (with its high population density) has emerged as a second hotspot. This area includes several Natural Parks and SNI but also other natural areas with no official protection status. The key role played by urban areas, especially the Metropolitan Area of Barcelona, but also the Metropolitan Area of Tarragona-Reus, is reinforced when we analyzed the distribution of rescues according to distance to the nearest town with over 100,000 people. There were increases for all three of the thresholds defined. Nevertheless, there was a clear pattern revealing a greater increase in the number of rescues with decreasing distance, with around $75 \%$ in the lowest distance $(<50 \mathrm{~km})$ when comparing data for 2020 with 2016-2019.

\subsection{Limitations}

This research does, however, have several limitations. We could not perform an indepth analysis into the relationship between the increase in the number of visitors to these 
natural areas and the increase in the number of rescues. Most of the protected natural areas in Catalonia received more visits in 2020 than in 2019, but there was a decrease in visits to others [52]. Unfortunately, there are no data available to quantify the increase for the whole territory. Data about visitors are limited to certain protected natural areas and, in some cases, the available data are not updated to the internet. We cannot therefore assert that the increase in the relative number of rescues has been either higher or lower than in the relative number of visitors.

Other divergences emerge when we compare the increase in the number of visitors and rescues associated with a concrete protected natural area. For example, the Aigüestortes i Estany de Sant Maurici National Park had a greater increase in the number of visitors than in the number of rescues, while just the opposite occurred at the Alt Pirineu Natural Park. Difficulties involved in establishing a pattern are more evident in the SNI, and other natural areas, where no estimation of the number of visitors is made. The number of rescues has increased significantly in some SNI, such as Muntanyes de Prades. We know that the number of visitors also increased, but by means of indirect sources, meaning we cannot quantify the increase.

Other limitations relate to the data about rescues. These include, for example, the lack of available information about: (1) the sociodemographic profiles of those rescued (age, sex, origin, etc.); (2) the number of people rescued in each rescue event; (3) the activities that the visitors were involved in before they needed to be rescued; (4) the number of people who were injured or died on a daily basis; and (5) the types of injury suffered.

\subsection{Implications and Future Research Lines}

Our data allowed us to achieve the objectives established in the introduction, and the results obtained could be of interest to emergency service managers, managers of protected natural areas, and public authorities. An increase in the number of rescues could compromise the efficiency of the emergency services if they were to occur simultaneously, especially if they required aerial support. This may make it necessary to increase or redistribute the resources currently available. Efficiency of the emergency services is even more compromised in the case of natural mountain areas. The complex orography and lack of suitable roads delay the answer of the terrestrial resources. Vehicles cannot reach where an accident took place. The orography and the presence of trees can also make the work of the aerial resources difficult. It is not possible to build an unlimited number of roads or provide suitable areas for helicopters, especially in protected natural areas, but the existing roads and suitable areas for helicopters have to be conveniently marked to facilitate the management of an emergency. At the same time, the efficiency of the emergency services improves if injured people can be quickly located utilizing their cell phones or GPS. Visitors to natural mountain areas can prevent or, at least, minimize the risk of suffering an incident if they are appropriately equipped (clothes, footwear, sufficient water, and food) including a cell phone [13]. The area should have good internet signal, which is not guaranteed in some mountain or remote area. These are not, however, the only implication for the Catalan Fire Department. Most wildfires occur in the summer, especially in the mountain chain that runs parallel to the coast (the Pre-littoral chain), which is near some of the most populated areas of Catalonia. Wildfires have also begun to pose a threat in the Pyrenees, partly due to climate change $[63,64]$. The summer of 2020 was exceptional in that there were relatively few wildfires and only a small, burned surface. However, having more people enjoying outdoor activities in natural areas increases the risk of both wildfires and people being trapped. It is therefore necessary to redefine the strategy used to fight against wildfires.

The increase in the number of rescues was linked to the increase in the number of visitors to natural areas. Several factors influence the number of visitors to a determined natural area, whether it is protected or not. These include both external and internal factors relating to conjunctural and structural situations. The end of the COVID-19 lockdown, restrictions to visit other destinations during the summer of 2020, and the perception of natural areas as safe places in terms of contagion were three external factors. A set of 
people who accessed the natural areas were unprepared to be in outdoor environments, and thus were more likely to have an accident. Undertaking a detailed analysis of each of the natural spaces, especially the protected ones, is therefore necessary. This must take into account their individual characteristics (high or medium-height mountains, wetlands, plateau, rocky coast, etc.) and the activities that can be enjoyed there, but also where they are located in terms of distance from the main populated areas and their connectivity and accessibility.

Although we could not determine the correlation between these two variables, we can assume that, as more people visit natural areas, the risk of them having accidents will increase, and some of these accidents will require the attention of the emergency services. The managers of protected natural areas had to face the sudden arrival of a large contingent of visitors in the summer of 2020. This could have had a negative impact on the natural resources of the protected areas by exceeding their carrying capacity. The managers of protected natural areas have to implement preventive measures to protect natural resources, but also to take appropriate action to prevent accidents [13,65].

A relevant question would be: do the managers of protected natural areas have sufficient budgets, staff, and infrastructure to provide appropriate answers to these challenges? One possible strategy to protect natural areas would be to restrict access to them. The threats and challenges are greatest when the protected natural area in question does not have a management team (or a budget or regular staff). A second relevant question would be: is this a one-off phenomenon that will be limited in time, or will it remain relevant in the future?

Managers of protected natural areas and environmental administrations, at the national, regional, and local levels, must design and apply short- and medium-term strategies adapted to the possible answers to the previous question. These questions open the way to new and more ambitious research involving all of the previously mentioned stakeholders, and focus on both the increase in the number of visitors to natural areas and the accidents that occur in them.

Author Contributions: Conceptualization, Ò.S.; methodology, Ò.S. and A.G.; cartography: E.B.; and writing and editing: Ò.S., E.B. and A.G. All authors have read and agreed to the published version of the manuscript.

Funding: This research was funded by the Chair of Sustainable Development Dow/URV, and the COVMOVTUR project (Fondo Supera COVID-19; Santander Bank, Conference of Rectors of Spanish Universities and Spanish National Research Council).

Data Availability Statement: Not applicable.

Acknowledgments: We would like to thank the Directorate-General of Fire Prevention, Extinction and Rescue (DGPEIS) of the Generalitat de Catalunya for providing data on rescues. The authors are members of the Research Group on Territorial Analysis and Tourism Studies at Universitat Rovira i Virgili (2017SGR22).

Conflicts of Interest: The authors declare no conflict of interest.

\section{References}

1. Taczanowska, K.; González, L.-M.; García-Massó, X.; Zięba, A.; Brandenburg, C.; Muhar, A.; Pellicer-Chenoll, M.; Toca-Herrera, J.-L. Nature-based Tourism or Mass Tourism in Nature? Segmentation of Mountain Protected Area Visitors Using Self-Organizing Maps (SOM). Sustainability 2019, 11, 1314. [CrossRef]

2. Butzmann, E.; Job, H. Developing a typology of sustainable protected area tourism products. J. Sustain. Tour. 2016, 25, 1736-1755. [CrossRef]

3. Jahani, A.; Goshtasb, H.; Saffariha, M. Tourism impact assessment modeling of vegetation density for protected areas using data mining techniques. Land Degrad. Dev. 2020, 31, 1502-1519. [CrossRef]

4. Mateos, A.; Leco, F.; Pérez, A. Visitors' Perception of the Overcrowding of a Protected Natural Area: A Case Applied to the Natural Reserve "Garganta de los Infiernos" (Caceres, Spain). Sustainability 2020, 12, 9503. [CrossRef]

5. Zhang, Y.; Xiao, X.; Zheng, C.; Xue, L.; Guo, Y.; Wu, Q. Is tourism participation in protected areas the best livelihood strategy from the perspective of community development and environmental protection? J. Sustain. Tour. 2019, 28, 587-605. [CrossRef] 
6. Siikamäki, P.; Kangas, K.; Paasivaara, A.; Schroderus, S. Biodiversity attracts visitors to national parks. Biodivers. Conserv. 2015, 24, 2521-2534. [CrossRef]

7. Martin, L.; White, M.P.; Hunt, A.; Richardson, M.; Pahl, S.; Burt, J. Nature contact, nature connectedness and associations with health, wellbeing and pro-environmental behaviours. J. Environ. Psychol. 2020, 68, 101389. [CrossRef]

8. Maldonado-Oré, E.M.; Custodio, M. Visitor environmental impact on protected natural areas: An evaluation of the Huaytapallana Regional Conservation Area in Peru. J. Outdoor Recreat. Tour. 2020, 31, 100298. [CrossRef]

9. Chamarro, A.; Fernández-Castro, J. The perception of causes of accidents in mountain sports: A study based on the experiences of victims. Accid. Anal. Prev. 2009, 41, 197-201. [CrossRef]

10. Hamonko, M.T.; McIntosh, S.E.; Schimelpfenig, T.; Leemon, D. Injuries Related to Hiking with a Pack During National Outdoor Leadership School Courses: A Risk Factor Analysis. Wilderness Environ. Med. 2011, 22, 2-6. [CrossRef]

11. Heggie, T.W.; Amundson, M.E. Dead Men Walking: Search and Rescue in US National Parks. Wilderness Environ. Med. 2009, 20, 244-249. [CrossRef] [PubMed]

12. Hung, E.K.; Townes, D.A. Search and Rescue in Yosemite National Park: A 10-Year Review. Wilderness Environ. Med. 2007, 18, 111-116. [CrossRef]

13. Boore, S.M.; Bock, D. Ten Years of Search and Rescue in Yosemite National Park: Examining the Past for Future Prevention. Wilderness Environ. Med. 2013, 24, 2-7. [CrossRef] [PubMed]

14. Goode, N.; Salmon, P.M.; Lenné, M.G.; Finch, C.F. Looking Beyond People, Equipment and Environment: Is a Systems Theory Model of Accident Causation Required to Understand Injuries and Near Misses During Outdoor Activities? Procedia Manuf. 2015, 3, 1125-1131. [CrossRef]

15. Amarowicz, J.; Kumorek, A.; Boczon, K. Age and Sex Are Strongly Correlated to the Rate and Type of Mountain Injuries Requiring Search and Rescue Missions. Wilderness Environ. Med. 2019, 30, 378-385. [CrossRef] [PubMed]

16. Gardner, T.B.; Hill, D.R. Illness and injury among long-distance hikers on the Long Trail, Vermont. Wilderness Environ. Med. 2002, 13, 131-134. [CrossRef]

17. Johnson, R.M.; Huettl, B.; Kocsis, V.; Chan, S.B.; Kordick, M.F. Injuries Sustained at Yellowstone National Park Requiring Emergency Medical System Activation. Wilderness Environ. Med. 2007, 18, 186-189. [CrossRef]

18. Pearce, E.A.; Jelínková, L.; Fullerton, L.; Malcolm, C.J.; Heinrich, H.L.; Norwil, E.J.; Plate, A.; Hall, M.; Bossart, C.S.; Schaller, E.; et al. Observational Study of Grand Canyon Rim-to-Rim Day Hikers: Determining Behavior Patterns to Aid in Preventive Search and Rescue Efforts. Wilderness Environ. Med. 2019, 30, 4-11. [CrossRef]

19. Ciesa, M.; Grigolato, S.; Cavalli, R. Retrospective Study on Search and Rescue Operations in Two Prealps Areas of Italy. Wilderness Environ. Med. 2015, 26, 150-158. [CrossRef] [PubMed]

20. Heggie, T.W.; Heggie, T.M. Search and Rescue Trends Associated With Recreational Travel in US National Parks. J. Travel Med. 2009, 16, 23-27. [CrossRef]

21. Lischke, V.; Byhahn, C.; Westphal, K.; Kessler, P. Mountaineering accidents in the European Alps: Have the numbers increased in recent years? Wilderness Environ. Med. 2001, 12, 74-80. [CrossRef]

22. WHO. Coronavirus Disease (COVID-19) Dashboard. Available online: https:/ / covid19.who.int/ (accessed on 8 February 2021).

23. BOE. Real Decreto 463/2020, de 14 de Marzo, por el Que se Declara el Estado de Alarma para la Gestión de la Situación de Crisis Sanitaria Ocasionada por el COVID-19. Boletín Oficial del Estado. Available online: https://confilegal.com/wp-content/ uploads/2020/04/BOE-355_Crisis_Sanitaria_COVID-19.pdf (accessed on 8 February 2021).

24. Beck, M.J.; Hensher, D.A. Insights into the impact of COVID-19 on household travel and activities in Australia-The early days under restrictions. Transp. Policy 2020, 96, 76-93. [CrossRef] [PubMed]

25. Chinazzi, M.; Davis, J.T.; Ajelli, M.; Gioannini, C.; Litvinova, M.; Merler, S.; Piontti, A.P.Y.; Mu, K.; Rossi, L.; Sun, K.; et al. The effect of travel restrictions on the spread of the 2019 novel coronavirus (COVID-19) outbreak. Science 2020, 368, 395-400. [CrossRef] [PubMed]

26. de Haas, M.; Faber, R.; Hamersma, M. How COVID-19 and the Dutch 'intelligent lockdown' change activities, work and travel behaviour: Evidence from longitudinal data in the Netherlands. Transp. Res. Interdiscip. Perspect. 2020, 6, 100150. [CrossRef]

27. Hadjidemetriou, G.M.; Sasidharan, M.; Kouyialis, G.; Parlikad, A.K. The impact of government measures and human mobility trend on COVID-19 related deaths in the UK. Transp. Res. Interdiscip. Perspect. 2020, 6, 100167. [CrossRef]

28. Kraemer, M.U.G.; Yang, C.-H.; Gutierrez, B.; Wu, C.-H.; Klein, B.; Pigott, D.M.; Du Plessis, L.; Faria, N.R.; Li, R.; Hanage, W.P.; et al. The effect of human mobility and control measures on the COVID-19 epidemic in China. Science 2020, 368, 493-497. [CrossRef]

29. Lau, H.; Khosrawipour, V.; Kocbach, P.; Mikolajczyk, A.; Ichii, H.; Zacharski, M.; Bania, J.; Khosrawipour, T. The association between international and domestic air traffic and the coronavirus (COVID-19) outbreak. J. Microbiol. Immunol. Infect. 2020, 53, 467-472. [CrossRef] [PubMed]

30. Wu, J.T.; Leung, K.; Leung, G.M. Nowcasting and forecasting the potential domestic and international spread of the 2019-nCoV outbreak originating in Wuhan, China: A modelling study. Lancet 2020, 395, 689-697. [CrossRef]

31. Uğur, N.G.; Akbıyık, A. Impacts of COVID-19 on global tourism industry: A cross-regional comparison. Tour. Manag. Perspect. 2020, 36, 100744. [CrossRef]

32. UNWTO. World Tourism Barometer. Available online: https://www.unwto.org/untwo-world-tourism-barometer-data (accessed on 8 February 2021). 
33. Brouder, P. Reset redux: Possible evolutionary pathways towards the transformation of tourism in a COVID-19 world. Tour. Geogr. 2020, 22, 484-490. [CrossRef]

34. Cheer, J.M. Human flourishing, tourism transformation and COVID-19: A conceptual touchstone. Tour. Geogr. 2020, 22, 514-524. [CrossRef]

35. Hall, C.M.; Scott, D.; Gössling, S. Pandemics, transformations and tourism: Be careful what you wish for. Tour. Geogr. 2020, 22, 577-598. [CrossRef]

36. Higgins-Desbiolles, F. The "war over tourism": Challenges to sustainable tourism in the tourism academy after COVID-19. J. Sustain. Tour. 2021, 29, 551-569. [CrossRef]

37. Nepal, S.K. Adventure travel and tourism after COVID-19-business as usual or opportunity to reset? Tour. Geogr. 2020, 22, 646-650. [CrossRef]

38. Lew, A.A.; Cheer, J.M.; Haywood, M.; Brouder, P.; Salazar, N.B. Visions of travel and tourism after the global COVID-19 transformation of 2020. Tour. Geogr. 2020, 22, 455-466. [CrossRef]

39. Romagosa, F. The COVID-19 crisis: Opportunities for sustainable and proximity tourism. Tour. Geogr. 2020, 22, 690-694. [CrossRef]

40. Manenti, R.; Mori, E.; Di Canio, V.; Mercurio, S.; Picone, M.; Caffi, M.; Brambilla, M.; Ficetola, G.F.; Rubolini, D. The good, the bad and the ugly of COVID-19 lockdown effects on wildlife conservation: Insights from the first European locked down country. Biol. Conserv. 2020, 249, 108728. [CrossRef] [PubMed]

41. Newsome, D. The collapse of tourism and its impact on wildlife tourism destinations. J. Tour. Futures 2020. [CrossRef]

42. Sustainable Recovery of Tourism in Protected Areas from the COVID-19 Pandemic. UNTWO. Available online: https: / www. unwto.org/COVID-19-oneplanet-responsible-recovery-initiatives/iucn-tapas-group (accessed on 8 February 2021).

43. Díaz-Sánchez, J.P.; Obaco, M. The effects of Coronavirus (COVID-19) on expected tourism revenues for natural preservation. The case of the Galapagos Islands. J. Policy Res. Tour. Leis. Events 2020, 1-5. [CrossRef]

44. COVID-19 Fallout Undermining Nature Conservation Efforts. IUCN. Available online: https://www.iucn.org/news/worldcommission-protected-areas/202103/COVID-19-fallout-undermining-nature-conservation-efforts-iucn-publication (accessed on 30 March 2021).

45. McGinlay, J.; Gkoumas, V.; Holtvoeth, J.; Armas Fuertes, R.F.; Bazhenova, E.; Benzoni, A.; Botsch, K.; Cabrera Martel, C.; Carrillo Sánchez, C.; Cervera, I.; et al. The impact of COVID-19 on the Management of European Protected Areas and Policiy Implication. Forests 2020, 11, 1214. [CrossRef]

46. Cues i Aglomeracions Sense Mascareta per Puja a la Pica d'Estats. Corporació Catalana de Mitjans Audiovisuals. Available online: https:/ / www.ccma.cat/324/cues-i-aglomeracions-sense-mascareta-per-pujar-a-la-pica-destats/noticia/3046557/ (accessed on 8 February 2021).

47. El Pirineu i el Montseny es Preparen Davant una Allau de Visitants de Barcelona a la Fuga. El Periódico. Available online: https:/ / www.elperiodico.cat/ca/societat/20201015/pirineu-montseny-garrotxa-allau-gent-barcelona-COVID-coronavirus-8157963/ (accessed on 8 February 2021).

48. Envaits. L'allau de Visitants col-Lapsa el Montseny. LíniaVallès. Available online: https://liniaxarxa.cat/liniavallesvallesoriental/noticies-destacades/envaits-lallau-de-visitants-collapsa-el-montseny/ (accessed on 8 February 2021).

49. Dudley, N. Guidelines for Applying Protected Area Management Categories; IUCN: Gland, Switzerland, 2008; ISBN 978-2-8317-1086-0.

50. Stolton, S.; Shadie, P.; Dudley, N. IUCN WCPA Best Practice Guidance on Recognising Protected Areas and Assigning Management Categories and Governance Types; Best Practice Protected Area Guidelines Series No. 21; IUCN: Gland, Switzerland, 2013.

51. Seraphin, H.; Dosquet, F. Mountain tourism and second home tourism as post COVID-19 lockdown placebo? Worldw. Hosp. Tour. Themes 2020, 12, 485-500. [CrossRef]

52. Sis Espais Naturals de Catalunya Han Doblat el Nombre de Visitants aquest Estiu. DTS. Available online: https://govern.cat/ govern/docs/2020/10/02/13/29/2cfff205-e928-499a-bfdd-dd0b4a323d28.pdf (accessed on 8 February 2021).

53. Més Rescats de Muntanya que mai tot i el Confinament. Diari Ara. Available online: https://www.ara.cat/societat/mes-rescatsmuntanya-confinament-coronavirus-COVID-19_1_1068939.html (accessed on 8 February 2021).

54. Creix el Nombre de Rescats a Rius, Gorgues i Camins de Ronda. Diari Públic. Available online: https://www.publico.es/public/ creix-nombre-rescats-rius-gorgues-i-camins-ronda.html (accessed on 8 February 2021).

55. El Creixement del Turisme de Proximitat Dispara els Rescats dels Bombers a L'estiu. Nació Digital. Available online: https: //www.naciodigital.cat/noticia/207605/creixement-turisme-proximitat-dispara-rescats-dels-bombers-estiu (accessed on 8 February 2021).

56. El Sistema d'Espais Naturals Protegits de Catalunya. Departament de Territori i Sostenibilitat. Available online: http:// mediambient.gencat.cat/ca/05_ambits_dactuacio/patrimoni_natural/senp_catalunya/(accessed on 8 February 2021).

57. IDESCAT. Turistes Estrangers amb Destinació Principal a Catdalunya. Variacions Internauals per País de Residència i any. Available online: https:/ / www.idescat.cat/visor / ?id=turest\&dataset=10\&tc=true\&tm=factor_ind_factor_tur,tasa_absoluta_ acumulada_tur,tasa_relativa_acumulada_tur\&td=t.any, terr.ccaa, proc.proc\&tf $=$ t.any[2020]\&cc=true\&cm =factor_ind_factor_tur, tasa_absoluta_acumula-da_tur,tasa_relativa_acumulada_tur\&cd=t.any, terr.ccaa,proc.proc\&cf=t.any[2020]\&filters=temps_2405 4.2020\&filters=territori_emtf_25077.09\&rows=n4_emtf_dim_pais_agr_25073\&columns=concept (accessed on 8 February 2021).

58. Sabet, M.S.; Asgary, A.; Solis, A.O. Emergency calls during the 2013 southern Ontario ice storm: Case study of Vaughan. Int. J. Emerg. Serv. 2019, 8, 292-314. [CrossRef] 
59. Mason, R.C.; Suner, S.; Williams, K.A. An Analysis of Hiker Preparedness: A Survey of Hiker Habits in New Hampshire. Wilderness Environ. Med. 2013, 24, 221-227. [CrossRef] [PubMed]

60. Soule, B.; Reynier, V.; Lefevre, B.; Boutroy, E. Who is at risk in the French mountains? Profiles of the accident victims in outdoor sports and mountain recreation. J. Mt. Sci. 2017, 14, 1490-1499. [CrossRef]

61. Rugg, C.; Tiefenthaler, L.; Rauch, S.; Gatterer, H.; Paal, P.; Ströhle, M. Rock Climbing Emergencies in the Austrian Alps: Injury Patterns, Risk Analysis and Preventive Measures. Int. J. Environ. Res. Public Health 2020, 17, 7596. [CrossRef] [PubMed]

62. Vanpoulle, M.; Lefevre, B.; Soule, B. Mountaineering incidents in France: Analysis of search and rescue interventions on a 10-year period (from 2008 to 2018). J. Mt. Sci. 2021, 18, 446-461. [CrossRef]

63. Batllori, E.; Parisien, M.-A.; Krawchuk, M.A.; Moritz, M.A. Climate change-induced shifts in fire for Mediterranean ecosystems. Glob. Ecol. Biogeogr. 2013, 22, 1118-1129. [CrossRef]

64. Duane, A.; Piqué, M.; Castellnou, M.; Brotons, L. Predictive modelling of fire occurrences from different fire spread patterns in Mediterranean landscapes. Int. J. Wildland Fire 2015, 24, 407-418. [CrossRef]

65. Kortenkamp, K.V.; Moore, C.F.; Sheridan, D.P.; Ahrens, E.S. No Hiking beyond this Point! Hiking Risk Prevention Recommendations in Peer-Reviewed Literature. J. Outdoor Recreat. Tour. 2017, 20, 67-76. [CrossRef] 